\title{
Unoccupied substrate in the central Great Barrier Reef: role of coral interactions
}

\author{
C. R. C. Sheppard* \\ Australian Institute of Marine Science, Townsville MSO, Queensland, Australia
}

\begin{abstract}
On 5 fore-reef slopes in the Great Barrier Reef and Coral Sea, unoccupied substrate ranged from 17 to $43 \%$ depending on depth and distance from shore. This is comparable with the few published values, but sits uneasily with concepts that space is a scarce resource. Mean substrate cover values in $2 \times 2 \mathrm{~m}$ plots were compared with values on substrate within interactive reach of coral colonies. In mid depths ( 7 to $10 \mathrm{~m}$ ) unoccupied substrate was significantly more abundant within interactive reach of corals than in plots as a whole. In shallower $(<5 \mathrm{~m})$ and deeper $(>15 \mathrm{~m})$ water, unoccupied substrate was not significantly greater next to corals than in sample plots. Coral colonies were completely absent within interactive reach of others in high diversity mid-depth plots, while in turbulent shallow water and in deep water, corals abutted others to a limited degree, although coral cover within reach of others was still significantly lower than in whole sample plots. It was concluded that corals maintain unoccupied substrate around themselves, especially in mid depths. Naturally occurring interactions in a diverse $10 \mathrm{~m}$ site had varying durations; $38 \%$ lasted longer than 1 yr but many lasted $<6$ mo. Interactions ended by death of subordinate colonies, growth out of reach, or from other miscellaneous events. Despite terminations, numbers remained near $7 \mathrm{~m}^{-2}$ due to convergence of established colonies (85\%) and newly recruited juveniles settling near adults (15\%). Calculation suggests that most substrate would pass under coral interactive mechanisms in about $20 \mathrm{yr}$. As distance from shore increased, total unoccupied substrate increased in shallow water $(<5 \mathrm{~m})$ and decreased in deep water $(>15 \mathrm{~m})$. In high diversity mid-depths there was no correlation of unoccupied substrate with distance from shore. In mid depths, 50 to $65 \%$ of unoccupied reef substrate lay within interactive reach of corals although only 5 to $25 \%$ of the total reef did so. Depths where most unoccupied substrate lay within interactive reach of coral colonies were $5 \mathrm{~m}$ on inshore and mid reefs, $10 \mathrm{~m}$ on the outer Great Barrier Reef, and $20 \mathrm{~m}$ in the Coral Sea. The interactive mechanisms of corals are important in the maintenance of unoccupied substrate on reef slopes.
\end{abstract}

\section{INTRODUCTION}

It is often assumed that space on a coral reef slope is limited, and that corals compete for it (e.g. Connell 1973, 1976, Rosen 1981). Aquisition of space in the light is presumed to be a main reason for coral competition, which increases with increasing diversity and colony abundance (Colgan 1982). However, in the few cases where unoccupied reef substrate has been measured, even crowded regions contain 20 to $35 \%$ of it (Bak \& Luckhurst 1980, Sheppard 1980, Bunt \& Williams 1982). Birkeland et al. (1982) noted that much unoccupied substrate may be present even in areas where there may be strong competition. Bak \& Luckhurst (1980) attributed unoccupied substrate partly to

\footnotetext{
- Present address: Marine Environmental Consultants Ltd., Chapel Cottage, Goodrich, Herefordshire HR9 6JH, United Kingdon
}

shifting sand, but otherwise there has been little work done on the questions of unoccupied reef substrate and its causes.

Studies of coral competition to date have concentrated on physiological aspects and their resulting dominance hierarchies (Glynn et al. 1972, Lang 1973, Connell 1976, Potts 1976, Richardson et al. 1979, Sheppard 1979, 1982a, Wellington 1980, Cope 1982, Chornesky 1983, Hidaka \& Yamazato 1984, Logan 1984). These studies reveal several competitive mechanisms which, together with external factors and competition from soft corals (Nishihira 1982, Sammarco et al. 1983), may lead to very complex hierarchies. While the mechanisms of these interactive abilities have been examined in some detail, their ecological consequences are less well studied.

The holistic approach to examining ecological effects of interactions is difficult because of the large 
number of conflicting factors. As a first step, l examine a readily observable but so far unquantified aspect of interactive mechanisms of corals, namely their ability to clear to some degree their surrounding substrate of other corals and perhaps of other organisms too. A band of unoccupied substrate killed by growing coral colonies was long ago recognised in both scientific and popular literature (Gravier 1910, Catala 1964), and the resulting band of cleared substrate has been called the 'corals' aura' (Faulkner \& Chesher 1979). It extends from 0.8 to about $10 \mathrm{~cm}$ from the edge of a colony depending on the interactive reach of the species (Sheppard 1982a). In this paper, I attempt to: (1) quantify unoccupied substrate on reef surfaces and determine whether any of it is attributible to coral colonies; (2) examine some of the relevant temporal aspects of coral interactions: (3) show the broad spatial pattern of unoccupied space across the Great Barrier Reef transect and determine what proportion of it might be accounted for by the interactive mechanisms of corals.

\section{METHODS AND STUDY AREA}

Survey plots were on seaward slopes of 5 reefs in the central Great Barrier Reef and Coral Sea (Fig. 1). These are the subject of cross-shelf studies which have identified several broad physical and biological patterns (Pickard 1977, Andrews \& Gentien 1982, Done 1982, Williams 1982, Dinesen 1983). Wave energy is greatest on the outermost Flinders and Myrmidon reefs and decreases towards shore. Sedimentation is greatest near shore on Pandora Reef and decreases seaward. The middle reefs have the greatest coral diversity.

The sites where each survey procedure was used are summarised in the caption to Fig. 1. In $2 \times 2 \mathrm{~m}$ plots, percent cover by fauna and unoccupied substrate in the plots as a whole was compared to that within interactive reach of coral colonies. Plots were in highdiversity areas at $10 \mathrm{~m}$ and $7.5 \mathrm{~m}$ deep on Myrmidon and Davies reef respectively, at $2 \mathrm{~m}$ deep in the wave exposed area of Myrmidon and at $25 \mathrm{~m}$ deep on Davies reef. Substrate cover values within interactive reach of coral colonies were recorded from contiguous areas around each coral colony out to their maximum reach. For many species this reach is given in Sheppard (1982a); if it was unknown, $1 \mathrm{~cm}$ was assigned as this is the minimum for most. Percent cover by bare substrate, corals, soft corals and algae was determined for the substrate around every colony and totalled for each plot. Total coral perimeter, and perimeter undergoing interaction with another species, was also measured.

To determine mean cover values in the plots as a whole, it was necessary to use measurements at points spaced at the same scale as that over which coral interactions reach, namely 1 to $10 \mathrm{~cm}$ (Sheppard 1982a). Therefore $5 \mathrm{~cm}$ intervals were used along a tape laid irregularly and randomly through the sample plots. In this application, the tape was laid along the reef through the plot such that in all places it was in contact with the substrate and followed all reef contours. In this way, even a $10 \mathrm{~m}$ tape (200 points) traverses a planar distance of sometimes less than $4 \mathrm{~m}$ depending on the reef micro-topography. The nature of the substrate at points $5 \mathrm{~cm}$ apart was recorded together with whether that point lay within interactive reach of a coral. From each plot, 200 to 1000 points were recorded, depending on time available at each site.

Three matters must be emphasised. Firstly, while

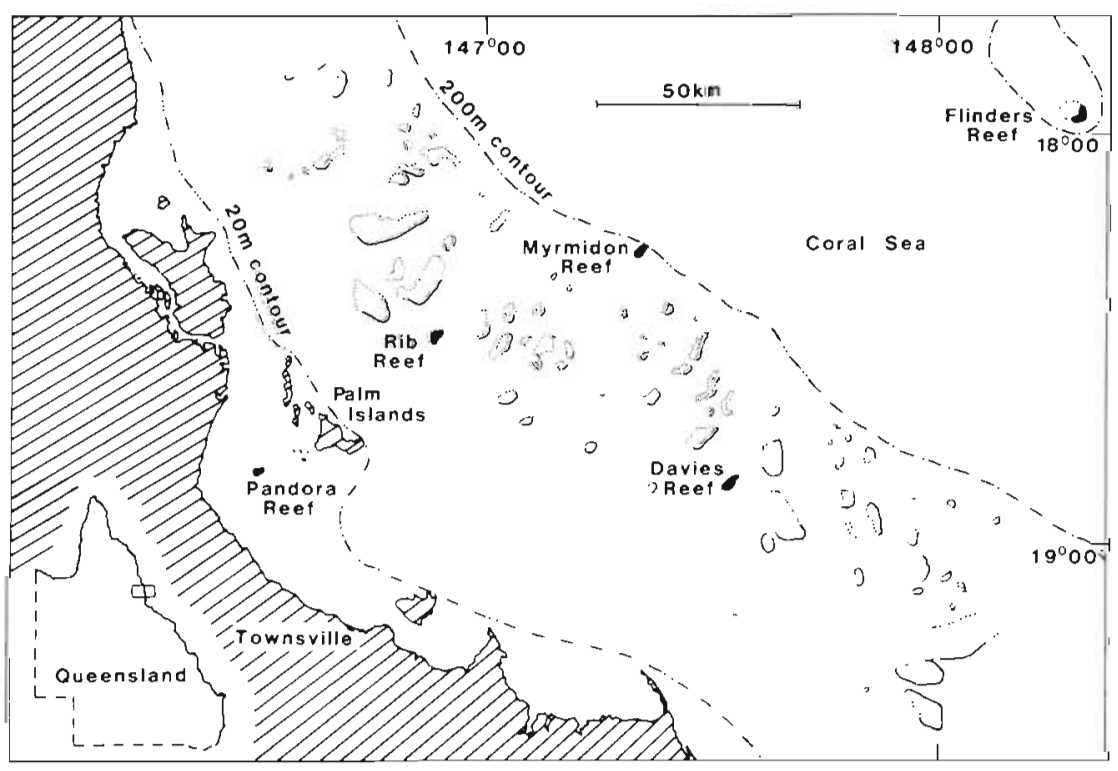

Fig. 1. The Great Barrier Reef off Townsville, Australia. The 5 study reefs are shown in black; continent and continental islands are hatched. The -20 and $-200 \mathrm{~m}$ contours are shown by broken lines and are taken from Maxwell (1968) Atlas of the Great Barrier Reef. The $2 \times 2$ plots used to investigate substrate occupancy were at 2 and $10 \mathrm{~m}$ on Myrmidon and 7.5 and $25 \mathrm{~m}$ on Davies Reefs. Permanent quadrats for temporal study were at $10 \mathrm{~m}$ on Davies Reef. Depths at intervals on all 5 reefs were used for cross-shelf measurement of unoccupied substrate 
point methods are less efficient in obtaining cover data in some circumstances, especially with large areas and scales (Weinberg 1981), at smaller scales comparisons have shown them to be no less accurate (Dodge et al. 1982). For obtaining detailed cover measurements within a few square metres, as in the present case, they are an efficient and common method of choice (Bak \& Luckhurst 1980).

Secondly, the spatial scale used in the measurement of cover values with the tapes is $5 \mathrm{~cm}$, which is the median of the scale over which interactions occur $(0.8$ to $10 \mathrm{~cm}$ ). This permits comparison between cover values of substrate in the plots as a whole and those of substrate within interactive reach of corals. Although $10 \mathrm{~m}$ or more of tape was laid to determine cover values in the plots as a whole, this does not mean that cover values for the plots were measured at a scale of metres or greater.

Thirdly, it is emphasised that the focus here is on 2 dimensional space at substrate level, (i.e. unoccupied substrate). The difficult problem of recording the contents of 3-dimensional space all around coral colonies is avoided, and is in practice largely unnecessary as parts of corals which project more than a few $\mathrm{cm}$ high are usually beyond interactive reach of other corals (see also Wellington 1980, Chornesky 1983).

Additional data were obtained from all 5 reefs using the tape method, at 2 or $5 \mathrm{~m}$ depth intervals to $30 \mathrm{~m}$ deep or to the foot of the reef slope. These were used to determine (1) the amount of unoccupied substrate at different depths and distances of the reef from shore, and (2) the proportion of the total unoccupied reef substrate which lay within interactive reach of corals.

At $10 \mathrm{~m}$ deep on the centrally located Davies Reef, 10 permanently marked quadrats totalling $11.2 \mathrm{~m}^{2}$ were examined at intervals of 3 mo for $1 \mathrm{yr}$, from March 1981. At first (Month 0), interactions in the quadrats were counted and descriptions and sketches were made to permit them to be relocated later. Photographs were taken of each quadrat to aid relocation, but their resolution was not adequate for taking measurements. In later visits, each interaction was reexamined to determine whether it continued, or the apparent cause of its termination. Newly commenced interactions were also recorded. Four categories of interaction termination were used: (1) the species previously noted to be subordinate had died; (2) the interacting part of the dominant coral had grown out of interaction range; $(3)$ the interacting part of the subordinate species had grown out of range; (4) a few miscellaneous terminations, including the breakage of an Acropora and the movement of a Fungia. Two categories of continuing interactions were used: (5) a stand-off, i.e. no noticable change; (6) the dominant species had advanced over the subordinate. Categories 5 and 6 grade into each other and are divided according to the resolution which can be achieved. In this case, movement of less than $1 \mathrm{~cm}$ was detectable using the descriptions and sketches made on each visit, but the 2 groups are in any case taken together for the present purpose and no conclusions are drawn which would depend on whether an ongoing interaction had advanced or was static. All the other categories were clearly defined and do not depend on reference to their earlier situation.

\section{RESULTS}

Before the main study, an examination under $\times 10$ magnification was made of unoccupied substrate from $10 \mathrm{~m}$ deep on the central Davies Reef. Samples of substrate were taken from less than $2 \mathrm{~cm}$ and from greater than $10 \mathrm{~cm}$ distant from any coral colony (Table 1). Under magnification, substrate which appears bare to a diver supports small amounts of biota, mainly filamentous algae. This result agrees with that obtained by Bunt \& Williams (1982) for the Caribbean region. Mean values of the contents of unoccupied substrate adjacent and not adjacent to coral colonies are very similar.

\section{Substrate occupancy within reach of corals}

Table 2 compares substrate occupancy within interactive reach of coral colonies with that in the total sample plots, in the high diversity regions of Myrmidon and Davies reefs respectively. The final rows show the significance of the difference between the 2 values, by T-test or Mann-Whitney U-test as appropriate, the

Table 1. Biotic cover revealed under $\times 10$ magnification of fragments of reef substrate which underwater appeared by naked eye to be unoccupied. Sample sizes are (A) $500 \mathrm{~cm}^{2}$ and (B) $230 \mathrm{~cm}^{2}$. Values are $\% \pm \mathrm{SE}$

\begin{tabular}{|c|c|c|}
\hline Category & $\begin{array}{c}\text { (A) }>10 \mathrm{~cm} \\
\text { from coral } \\
\text { colonies }\end{array}$ & $\begin{array}{c}\text { (B) }<2 \mathrm{~cm} \\
\text { from coral } \\
\text { colonies }\end{array}$ \\
\hline No surface biota & $31 \pm 9$ & $40 \pm 7.6$ \\
\hline $\begin{array}{l}\text { No surface biota, }+ \text { endolithic } \\
\text { green algae }\end{array}$ & $20 \pm 10$ & $17 \pm 5$ \\
\hline $\begin{array}{l}\text { Scattered filamentous greens } \\
\text { on bare rock }\end{array}$ & $15 \pm 9$ & $13 \pm 6$ \\
\hline $\begin{array}{l}\text { Scattered filamentous reds on } \\
\text { bare rock }\end{array}$ & $18 \pm 12$ & $8 \pm 4$ \\
\hline $\begin{array}{l}\text { Encrusting red algal flecks } \\
\text { on bare rock }\end{array}$ & $15 \pm 5.5$ & $22 \pm 7$ \\
\hline $\begin{array}{l}\text { Bryozoans, apertures to boring } \\
\text { sponge tunnels, } \\
\text { serpulids, sponge }\end{array}$ & 1 & 1 \\
\hline
\end{tabular}


Table 2. Comparison of cover values of substrate lying within interacting reach of corals with total cover values of the sample plots. (A) Myrmidon Reef, $10 \mathrm{~m}$ depth, (B) Davies Reef, $7.5 \mathrm{~m}$ depth. Values are \% of total $\pm \mathrm{SE}$

\begin{tabular}{|c|c|c|c|c|c|}
\hline & Coral & $\begin{array}{l}\text { Unoccupied } \\
\text { substrate }\end{array}$ & $\begin{array}{l}\text { Unoccupied } \\
\text { minus inter- } \\
\text { acting zones }\end{array}$ & $\begin{array}{l}\text { Red } \\
\text { algae }\end{array}$ & $\begin{array}{c}\text { Non- } \\
\text { scleractinian } \\
\text { coelenterates }\end{array}$ \\
\hline \multicolumn{6}{|c|}{ A. Myrmidon Reef } \\
\hline $\begin{array}{l}\text { Substrate within } \\
\text { reach of corals }\end{array}$ & 0 & $54.2 \pm 2.8$ & $40.8 \pm 3.2$ & $41.0 \pm 3.0$ & $4.8 \pm 1.0$ \\
\hline Total $2 \times 2 \mathrm{~m}$ plot & $37.0 \pm 4.2$ & $17.0 \pm 4.8$ & $8.5 \pm 5.0$ & $23.5 \pm 3.2$ & $20.5 \pm 7.5$ \\
\hline Significance & $\mathrm{p}<.001$ & $\mathrm{p}<.002$ & $p<.05$ & NS & $p<.002$ \\
\hline \multicolumn{6}{|c|}{ B. Davies Reef } \\
\hline $\begin{array}{l}\text { Substrate within } \\
\text { reach of corals }\end{array}$ & 0 & $66.6 \pm 3.5$ & $48.2 \pm 4.1$ & $28.5 \pm 3.5$ & $5.9 \pm 1.9$ \\
\hline Total $2 \times 2 \mathrm{~m}$ plot & $46.0 \pm 4.5$ & $28.3 \pm 2.7$ & $22.4 \pm 2.7$ & $15.4 \pm 4.7$ & $8.8 \pm 5.0$ \\
\hline Significance & $p<.001$ & $p<.02$ & $p<.05$ & NS & NS \\
\hline NS Not significant & & & & & \\
\hline
\end{tabular}

former being used only when the data had a normal distribution, or when the mean was not zero.

The most striking feature is the total absence of other corals within reach of coral colonies. The difference in coral cover between this area and that in the plots as a whole is highly significant. Also significant is the difference of percent unoccupied substrate in the 2 categories. Whereas the values in the plots as a whole are 17 and $28 \%$ for Mymidon and Davies reefs respectively, which agree with other literature values (Bak \& Luckhurst 1980, Sheppard 1980, Bunt \& Williams 1982), next to corals they are 2 to 3 times greater.

The third column of Table 2 compares a subset of the unoccupied space; it refers to unoccupied substrate where there is no current coral-coral conflict because corals are not sufficiently close. In other words, this is unoccupied substrate which lies within interactive reach of 1 coral colony only. This also shows a significant difference in the 2 conditions. (This category of substrate is also one of the components in the second column of total unoccupied substrate, and is the rea- son why addition of all substrate categories exceeds $100 \%$ ).

In contrast, red algae cover is not significantly different, while non-scleractinian coelenterates have significantly lower cover next to corals on Myrmidon Reef but not on Davies Reef.

The same comparisons were carried out on the $2 \mathrm{~m}$ depth plot on Myrmidon reef. This lies on the outer edge of the Great Barrier Reef. It is very turbulent and the delicate interaction mechanisms may be impeded. In this case (Table 3), unoccupied space next to corals is very similar to that of the plot as a whole. Another contrast to the plots at 7 to $10 \mathrm{~m}$ is that corals can exist immediately adjacent to other species, although this value $(11 \%)$ is still significantly lower than the coral cover for the plot generally. Most of the species which abutted in this plot were Acropora spp. Red algae commonly abutted corals, while soft corals were absent from the plot.

A third comparison was performed in the plot at $25 \mathrm{~m}$ on Davies reef (Table 4). There, coral cover was lower

Table 3. Comparıson of cover values of substrate lying within interacting reach of corals with total cover in the sample plot in the exposed reef slope at $2 \mathrm{~m}$ depth on Myrmidon Reef. Values are \% of total $\pm \mathrm{SE}$

\begin{tabular}{|c|c|c|c|c|c|}
\hline & Coral & $\begin{array}{l}\text { Unoccupied } \\
\text { substrate }\end{array}$ & $\begin{array}{l}\text { Unoccupied } \\
\text { minus inter- } \\
\text { acting zones }\end{array}$ & $\begin{array}{l}\text { Red } \\
\text { algae }\end{array}$ & $\begin{array}{c}\text { Non- } \\
\text { scleractinian } \\
\text { coelenterates }\end{array}$ \\
\hline $\begin{array}{l}\text { Substrate within } \\
\text { reach of corals }\end{array}$ & $11.0 \pm 1.9$ & $25.5 \pm 2.0$ & $19.4 \pm 2.9$ & $63.5 \pm 3.3$ & 0 \\
\hline Total $2 \times 2 \mathrm{~m}$ plot & $44.5 \pm 9.5$ & $23.2 \pm 4.3$ & $19.0 \pm 1.9$ & $32.3 \pm 7.0$ & 0 \\
\hline Significance & $p<.001$ & NS & NS & $p<.05$ & NS \\
\hline
\end{tabular}


Table 4. Comparison of cover values of substrate lying within interacting reach of corals with total cover in the sample plot at 25 $m$ depth on Davies Reef. Values are \% of total \pm SE

\begin{tabular}{|c|c|c|c|c|c|}
\hline & Coral & $\begin{array}{l}\text { Unoccupied } \\
\text { substrate }\end{array}$ & $\begin{array}{l}\text { Unoccupied } \\
\text { minus inter- } \\
\text { acting zones }\end{array}$ & $\begin{array}{l}\text { Red } \\
\text { algae }\end{array}$ & $\begin{array}{c}\text { Non- } \\
\text { scleractinian } \\
\text { coelenterates }\end{array}$ \\
\hline $\begin{array}{l}\text { Substrate within } \\
\text { reach of corals }\end{array}$ & $2.0 \pm 0.3$ & $60.5 \pm 4.4$ & $52.5 \pm 3.4$ & $32.9 \pm 3.4$ & $4.0 \pm 1.3$ \\
\hline Total $2 \times 2 \mathrm{~m}$ plot & $26.0 \pm 5.5$ & $43.0 \pm 2.0$ & $34.5 \pm 3.3$ & $18.0 \pm 1.6$ & $8.5 \pm 1.7$ \\
\hline Significance & $\mathrm{p}<.001$ & NS & NS & NS & NS \\
\hline
\end{tabular}

than in the peak diversity region at 7 to $10 \mathrm{~m}$, and agariciids and dendrophylliids were common. The results show that at this depth or with these corals, $2 \%$ of corals, notably from the above 2 families, can abut others, but this value is still significantly lower than the average $26 \%$ coral cover of the plot. The mean differences in other parameters, while following the same trend, are not significant.

To summarize, in the high diversity regions of the reef slopes the percent cover by unoccupied substrate is significantly greater within interactive reach of coral colonies than it is in the sample plots as a whole. Also, corals are completely absent within interactive reach of others. In turbulent, shallow water or in deep water, corals are still significantly less common within interactive reach of others than in the plots as a whole although Acropora spp. in shallow water and agariciids and dendrophylliids in deeper water can abut each other to some degree. In such areas, unoccupied space is not significantly greater next to coral colonies.

\section{Temporal changes}

In the 10 permanently marked quadrats at $10 \mathrm{~m}$ depth on Davies Reef, as well as on Myrmidon at both 2 and $10 \mathrm{~m}$, corals had 5 to $5.6 \mathrm{~m}$ of colony perimeter $\mathrm{m}^{-2}$ at substrate level. With an average reach of $1 \mathrm{~cm}, 5 \%$ of the reef surface falls within interactive reach of corals at any 1 time. In fact, a more realistic figure (Sheppard 1982a) means that up to one-third of the total substrate could lie within interactive reach of the perimeters of corals. Many of the corals also grow, so that the exact parts of the substrate which are affected change.

This temporal aspect was examined over 1 yr. Substrate changes could not usefully be measured in the manner of Bak \& Luckhurst (1980) since only 1 yr was available compared with their $5 \mathrm{yr}$. Instead, coral interactions and their progressions were directly examined.

Initially, there were 6.0 coral-coral interactions $\mathrm{m}^{-2}$ $(\mathrm{SE}=0.52)$ and 4.4 coral-soft coral interactions $\mathrm{m}^{-2}$ $(\mathrm{SE}=0.66)$. Interactions between corals and other faunal groups were less than $0.5 \mathrm{~m}^{-2}$. Fig. 2 shows the fate of the coral-coral interactions over the year. The width of the various blocks on the figure are proportional to the numbers of pairs involved. From an initial 67 interacting coral pairs, or $6.0 \mathrm{~m}^{-2}, 43 \%$ had terminated at Month 6 for the reasons shown. However, at the same time newly initiated interactions increased the total number to $7.1 \mathrm{~m}^{-2}$. A similar result was obtained after $12 \mathrm{mo}$, when $40 \%$ of interactions which existed 6 mo previously had ceased, and an input of new ones maintained the number at $7.2 \mathrm{~m}^{-2}$.

Although the 6 mo intervals give an artificially stepped appearance, the terminations of interactions and emergence of new ones is obviously a continuous process. The durations of interactions vary considerably. Of initial interactions, $57 \%$ remained after 6 mo and $38 \%$ were still present after 1 yr. There is a mixture therefore of many relatively brief conflicts and fewer long-lasting ones.

During the year about 4 interactions $\mathrm{m}^{-2}$ appeared, which is marginally greater than the rate of terminations. Two main causes for new interactions exist: $85 \%$ were due to converging perimeters of growing colonies, and only $15 \%$ were due to newly settled juveniles. Newly settled corals total $7.0 \mathrm{~m}^{-2}$, but of these only about $1 \mathrm{~m}^{-2}$ were close enough to another coral to be seen interacting. Where a juvenile was observed interacting it was always the dominant of the pair. This is probably largely because if a subordinate recruit settles within interaction reach of another and is killed it will be almost impossible to detect.

In this diverse plot, 1 to 2 colonies $\mathrm{m}^{-2}$ were completely killed each year through interactions, excluding unnoticed juveniles. An additional 1 colony $\mathrm{m}^{-2}$ was completely killed through interaction with soft 


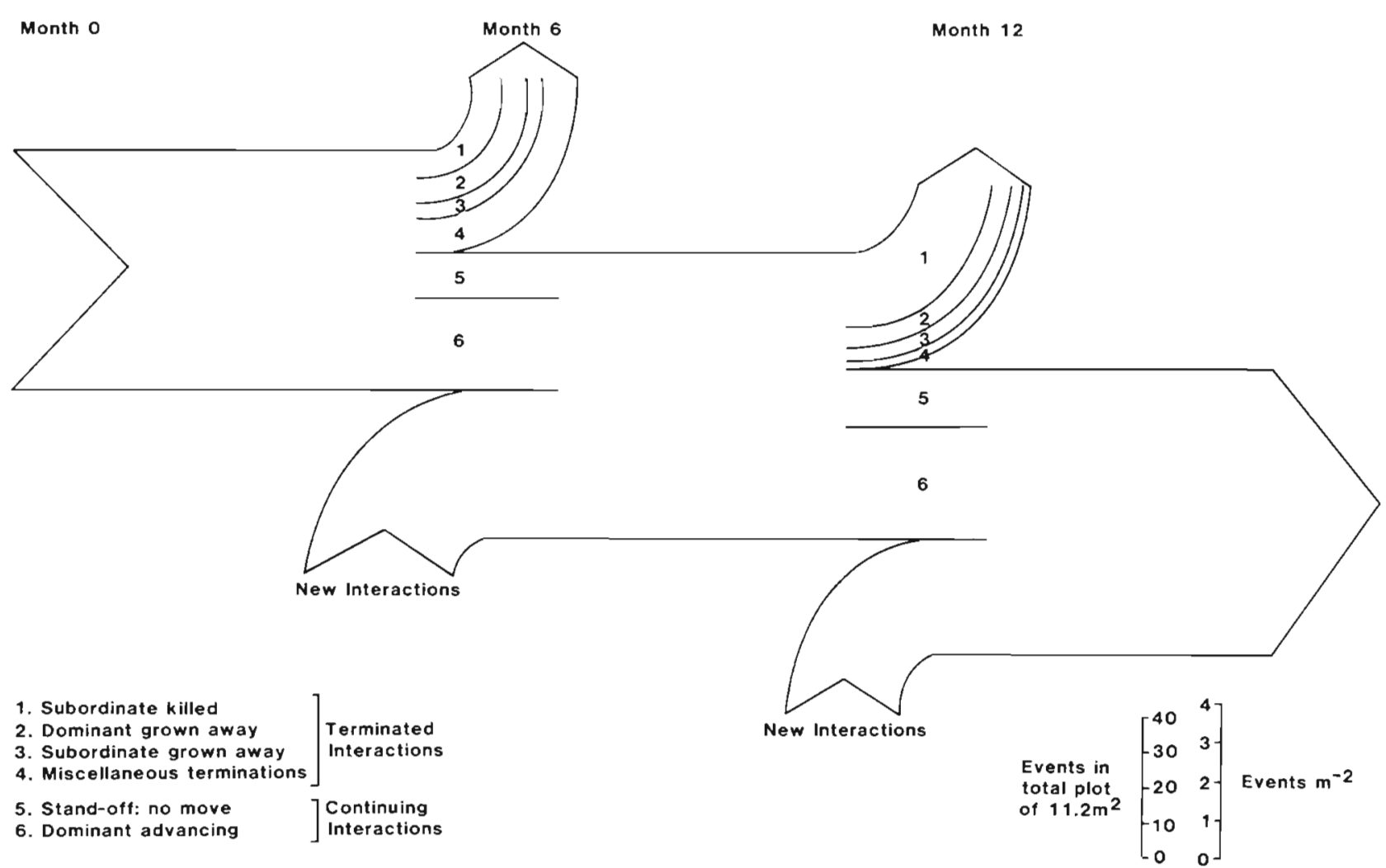

Fig. 2. Results of coral interactions in 10 permanent quadrats whose planar area totals $11.2 \mathrm{~m}^{2}$. Sample plot was at $10 \mathrm{~m}$ depth on seaward slope of Davies Reef. Widths of blocks are drawn to scale, showing interaction events which terminate (1 to 4$)$, events which persist $(5,6)$ and new interactions

corals. Therefore $5.3 \%$ of the non-juvenile (but always small) colonies died in the year by falling within interaction reach of adjacent dominant corals whose perimeters were growing outwards.

Only $1.4 \%$ of interactions showed a reversed dominance during the year (accounted for in category 4 of Fig. 2). This is much less than the proportion found by Bak et al. (1982) in Curacao and is much closer to the value found by Logan (1984) from Bermuda.

\section{Distribution of unoccupied space with depth and dis- tance from shore}

Using all the line transect data, the pattern of total unoccupied substrate at several depths on all 5 study reefs is shown in Fig. 3. Reefs are ordered (left to right) according to distance from the mainland. At 2 and $5 \mathrm{~m}$ depth, there is an increasing amount of unoccupied substrate as distance from the shore increases. At $10 \mathrm{~m}$ there is no clear trend, while at $15 \mathrm{~m}$ and greater there is a reversed trend with a smaller amount of unoccupied substrate with increasing distance offshore. Spearman's rank correlation (Fig. 3) confirms the significance of the trends.

The gradients of unoccupied substrate in the shallow and deep regions broadly correspond with the known environmental gradients of wave energy and sedimentation on this part of the Great Barrier Reef (Pickard 1977, Done 1982; see 'Discussion'). The trends of total unoccupied space observed at these depths therefore may be largely explained by these physical gradients although this aspect was not studied.

The high cover by unoccupied substrate at mid depths, however, and its lack of a gradient with distance from shore, is not explained by physical controls. Indeed, at mid depths the sum of the physical controls is at its minimum (Chappell 1980) and is unlikely to account for the large proportion of unoccupied space. However, when the proportion of the total unoccupied substrate which lies within interactive reach of a coral colony is plotted (Fig. 4), in every case this subset of unoccupied space shows a rise and then a fall with increasing depth. Moreover, the depth of each peak occurs at a greater depth as the distance of the reef from shore increases. In these mid depths, as much as 50 to $65 \%$ of the unoccupied substrate falls within reach of coral colonies, although only 5 to $25 \%$ of the total reef surface does so. This contrasts with shallow and deep areas where the amount of unoccupied substrate falling within reach of corals is similar to that for the total reef surface. 


\section{DISCUSSION}

The different substrate occupancy in the zone within interaction reach of coral colonies compared with the sample plots as a whole suggests that corals can clear their immediate surroundings of other fauna, especially other corals. This 'corals' aura' (Faulkner \& Chesher 1979) is not a purely physical effect caused, for example, by microcurrents or shading, because the width of the unoccupied band around each colony is fairly consistent for a given species (Sheppard 1982a) and is not seen around non-living limestone. Also it is known that development of an aggressive response depends not on physical conditions but on the proximity of other corals (Chornesky 1983).

Although coral interactive mechanisms clearly create and maintain space, so do many other biological and physical factors, notably the effects of grazers, mobile sediments and toxin-excreting invertrebrates (e.g. Branham et al. 1971, Glynn 1976, Neudecker 1979, Bak \& Luckhurst 1980, Sammarco 1980, Bakus 1981, Birkeland et al. 1981). The relative importance of any of these biological mechanisms has not been estimated, and even the quantity of space on reefs appears to have been overlooked in many studies.

Other reported values for unoccupied space on reef slopes are: 20 to $30 \%$ in Chagos (Sheppard 1980), $28 \%$ in Curacao on 2 occasions (Bak \& Luckhurst 1980), and $28 \%$ in the Bahamas (Bunt \& Williams 1982). Values found here are of the same order, but span a greater range and show gradients with both depth and distance from shore. In very shallow and in deep water, the gradients of total benthic space across the 5 reefs correlate with known environmental gradients (Pickard 1977, Andrews \& Gentien 1982). In shallow areas where wave energy increases towards offshore reefs, total benthic space increases. In deep areas where sedimentation increases and illumination falls towards shore, unoccupied substrate again correlates with the more severe conditions. It is likely that these physical controls are largely responsible for the maintenance of space in these stressed parts of the reefs (Done 1982), and in broad terms there is little doubt that it is principally these major physical factors which shape a reef and its general biological character (Sheppard 1982b).

At the centimetre scale on hard substrate, unoccupied space in high-diversity areas of this study is 17 to $28 \%$ (Table 2). High values such as this are difficult to explain, although in Curaçao, Bak \& Luckhurst (1980) attribute much of it to mobile sediments. On the present series of reefs, in mid depths where the importance of physical factors diminishes, the proportion of total unoccupied substrate which lies within the interactive reach of corals increased to $50 \%$ or more (Fig. 4). This implicates interactive mechanisms of
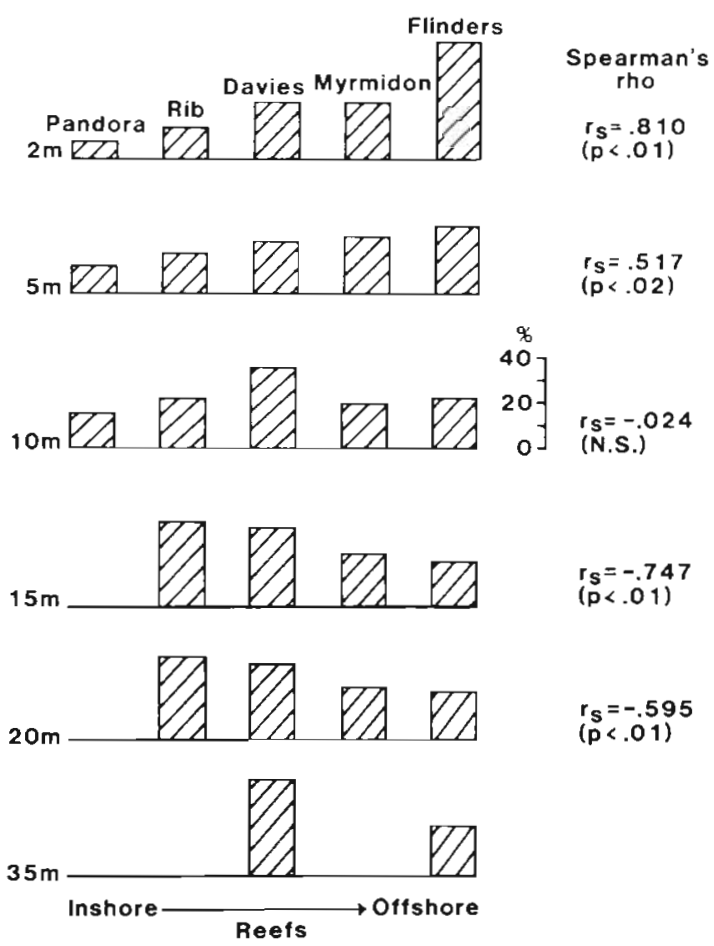

Fig. 3. Total unoccupied substrate (\%) at several depths on the 5 study reefs. Reefs are ordered (left to right) by increasing distance from shore and from the $-20 \mathrm{~m}$ contour (see Fig. 1). Correlation coefficients (Spearman rho) of ranked data show significance and sign of the trend at each depth. Values at 25 and $30 \mathrm{~m}$ were identical to $35 \mathrm{~m}$ and are omitted
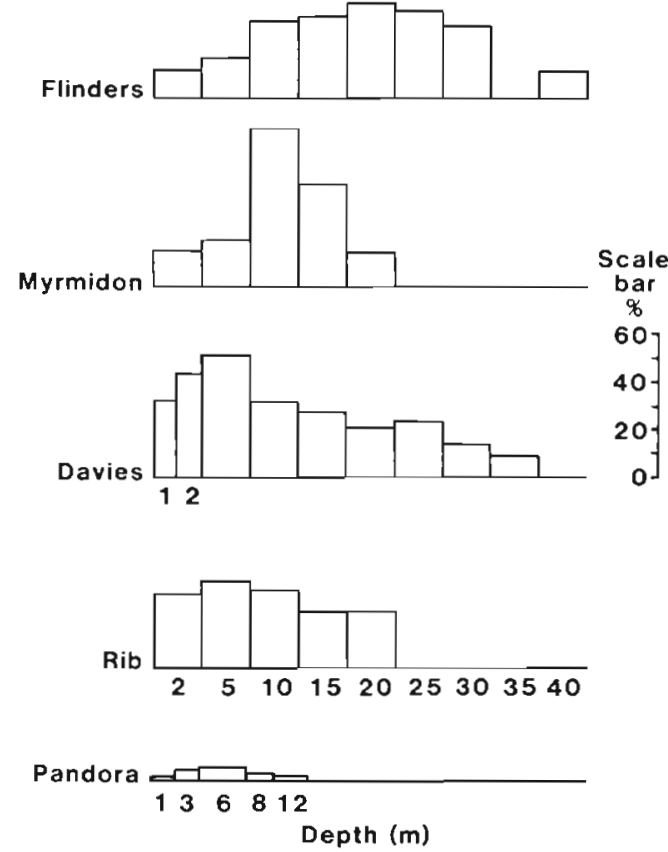

Fig. 4. Percent of total unoccupied space which lies within interactive reach of a coral, plotted against depth for each reef. Depths are shown beneath plot for Rib Reef. (At Davies Reef 1 and $2 \mathrm{~m}$ depths were examined, while at Pandora reef depths were measured as shown) 
corals in the creation and maintenance of space. Several soft corals and sponges on reefs kill neighbouring fauna also (Bryan 1973, Coll et al. 1982, Nishihira 1982, Sammarco et al. 1983), so it may be found that even more benthic space falls within lethal range of competitive, benthic fauna than that which is accounted for by corals alone. It is likely that much of the unoccupied space is unoccupiable.

In the permanently marked quadrats it was seen that coral interactions are not static. Of new interactions, $85 \%$ arise from growing edges. Growth rates of encrusting edges of corals are commonly 0.5 to $2 \mathrm{~cm} \mathrm{yr}^{-1}$ or more (Buddemeier \& Kinzie 1976), so that the substrate around corals from which other benthic organisms are excluded or greatly reduced is not static but moves at a rate related to the growth of the colony perimeters. By calculation, the growth of colonies will sooner or later bring most of the substrate under the influence of the interactive mechanism of corals in about 20 yr. While the total cover of corals, unoccupied substrate or other components may remain relatively unchanged over time in any one quadrat, the components beneath any one point may repeatedly change. A similar observation by Bak \& Luckhurst (1980) in Curaço led them to remark that community organisation is more influenced by spatial rearrangement of its components than had previously been recognised. The present study confirms this, and suggests that at the 1 to $10 \mathrm{~cm}$ scale, aggressive mechanisms of corals help create a condition of considerable flux in the spatial arrangement of unoccupied space and benthic species.

Interactions may have effects which result from the creation of unoccupied substrate. At the level of the individual, competitive mechanisms develop specifically to counter incursive threats from neighbours (Chornesky 1983) and result in occupation of space taken by other species (Sheppard 1982a). Such competition is considered to be one of the processes structuring reef communities and shaping life history attributes (Connell 1973, 1978, Porter 1974, 1976, Jackson 1977, Bak \& Engel 1979). Further, a model by Karlson \& Jackson (1981) showed that overgrowth rates - analogous to interactiveness here - are more consequential to final community structure than several other life history attributes, while Buss (1981) showed how interactions provide selective pressures which lead to the evolution of cooperation and group living.

However, some authors have stated that interactions have little consequence to community structure. Bak et al. (1982) felt that this was the case in Curaçao because of the many other factors involved and because they found a low predictability of the outcome of interactions. Regional differences are possible in the latter respect, since Logan (1984) reported a highly predictable outcome of interactions in Bermuda. In the Carib- bean, regional differences in the coral aggression hierarchy have been noted in islands as closely adjacent as Jamaica and Little Cayman (Logan 1984), while in the Indo-Pacific, marked differences occured between Chagos (Sheppard 1979), the present study reefs in the Great Barrier Reef, and the central Red Sea where coral interactions are rare events in some parts (pers. obs.).

Bradbury \& Young (1982) also state that interactions have no discernible effect on community structure because they found that coral colonies in their study had neighbours of random identity. However, their recording interval (mean of $20 \mathrm{~cm}$ but up to $40 \mathrm{~cm}$ ) was greater than the interactive reach of any coral so that interactions could not affect corals at adjacent recording points, and unoccupied space was not considered. Also their study was on a reef flat where biological controls would not be expected to be as important as physical ones. Their generalised interpretation means not only that interactions but in fact no attribute of corals affects their distribution at this scale; to date, there is insufficient evidence to support this. Indeed, the 'random neighbour' method itself has been entertainingly dismissed by Feinsinger et al. (1981; see also Grant \& Abbott 1980).

The present study suggests that coral interactions are important in the consideration of unoccupied substrate on high diversity parts of these reef slopes. The degree to which they are important in community structure is likely to be related to the importance of the unoccupied substrate itself. In terms of providing space for new recuritment this may not be as great as the amount of space might indicate, since recruitment into space within interactive reach of corals might be shortlived. The importance attached to maintaining a continuous turnover of substrate occupancy as coral perimeters grow, however, may prove to be of greater importance.

Acknowledgements. This work was carried out during the tenure of a Postdoctoral Fellowship at the Australian Institute of Marine Science. I thank Drs Paul Sammarco and J. E. N. Veron for useful comments on the manuscript, and A. Sheppard for extensive assistance in the field.

\section{LITERATURE CITED}

Andrews, J. C., Gentien, P. (1982). Upwelling as a source of nutrients for the Great Barrier Reef ecosystems: a solution to Darwin's question? Mar. Ecol. Prog. Ser. 8: 257-269

Bak, R. P. M., Engel, M. S. (1979). Distribution, abundance and survival of juvenile hermatypic corals (Scleractinia) and the importance of life history strategies in the parent coral community. Mar. Biol. 54: 341-352

Bak, R. P. M., Luckhurst, B. E. (1980). Constancy and change 
in coral reef habitats along depth gradients at Curaçao. Oecologia (Berl.) 47: 145-155

Bak, R. P. M., Termaat, R. M., Dekker, R. (1982). Complexity of coral interactions: influence of time, location of interaction and epifauna. Mar. Biol. 69: 215-222

Bakus, G. J. (1981). Chemical defense mechanisms on the Great Barrier Reef, Austra]ia. Science, N. Y. 211. 497-499

Birkeland, C., Cheng, L., Lewin, R. A. (1981). Motility of didemnid ascidian colonies. Bull. mar. Sci. 31: 170-173

Birkeland, C., Rowley, D., Randall, R. H. (1982). Coral recruitment patterns at Guam. Proc. 4th Int. Coral Reef Symp, Manila, 1981, 2: 339-344

Bradbury, R. H., Young, P. C. (1982). The race and the swift revisited, or is aggression between corals important? Proc 4th Int. Coral Reef Symp. Manila, 1981, 2: 351-356

Branham, J. M., Reed, S. A., Bailey, J. H. Caperon, J. (1971). Coral eating sea stars Acanthaster planci in Hawaii. Science N. Y. 172: 1155-1157

Bryan, P. G. (1973). Growth rate, toxicity and distribution of the encrusting sponge Terpios sp. (Hadromerida: Suberitidae) in Guam, Marianas Islands. Micronesica 9: $237-242$

Buddemeier, R. W., Kinzie, R. A. (1976). Coral growth. Oceanogr. mar. Biol. A. Rev. 14: 183-225

Bunt, J. S., Williams, W. T. (1982). Standing stocks of organic carbon associated with sessile reefal communities in the Bahamian region. Austr. Inst. Mar. Sci. data rep.: RS-82-1

Buss, L. W. (1981). Group living, competition, and the evolution of cooperation in a sessile invertebrate. Science, N. Y. 213: 1012-1014

Catala, R. L. A. (1964). Camival sous la mer. R. Sicard, Paris

Chappell, J. (1980). Coral morphology, diversity and reef growth. Nature, Lond. 286: 249-252

Chornesky, E. A. (1983). Induced development of sweeper tentacles on the reef coral Agaricia agaricites: a response to direct competition. Biol. Bull. mar. biol. Lab., Woods Hole 165: 569-581

Colgan, M. W. (1982). Succession and recovery of a coral reef after predation by Acanthaster planci (L.). Proc. 4th Int. Coral Reef Symp. Manila, 1981, 2: 333-338

Coll, J. C., LaBarre, S., Sammarco, P. W., Williams, W. T., Bakus, G. J. (1982). Chemical defenses in soft corals (Coelenterata: Octocorallia) of the Great Barrier Reef: a study of comparative toxicities. Mar. Ecol. Prog. Ser. 8: $271-278$

Connell, J. H. (1973). Population ecology of reef building corals. In: Jones, O. A., Endean, R. (ed.) Biology and geology of coral reefs, Vol 2, Biol. 1. Academic Press, London, p. 205-245

Connell, J. H. (1976). Competitive interactions and the species diversity of corals. In: Mackie, G. O. (ed.) Coelenterate ecology and behaviour. Plenum Press, New York, p. $51-58$

Connell, J. H. (1978). Diversity in tropical rain forests and coral reefs. Science, N. Y. 199: 1302-1310

Cope, M. (1982). Interspecific coral interactions in Hong Kong. Proc. 4th Int. Coral Reef Symp. Manila, 1981, 2: $357-362$

Dinesen, Z. D. (1983). Patterns in the distribution of soft corals across the central Great Barrier Reef. Coral Reefs 4: 229-236

Dodge, R. E., Logan, A., Antonius, A. (1982). Quantitative reef assessment studies in Bermuda: a comparison of methods and preliminary results. Bull. mar. Sci. 32: 745-760

Done, T. J. (1982). Patterns in the distribution of coral communities across the central Great Barrier Reef. Coral Reefs 1: $95-107$
Faulkner, D., Chesher, R. (1979). Living corals. Potter, New York

Feinsinger, P., Whelan, R. J., Kiltie, R. A. (1981). Some notes on community composition: assembly by rules or by dartboards? Bull. ecol. Soc. Am. (1981) p. 19-23

Glynn, P. W (1976). Some physical and biological determinants of coral community structure in the eastern Pacific. Ecol. Monogr. 46: 431-456

Glynn, P. W., Stewart, R. H., McCosker, J. E. (1972). Pacific coral reefs of Panama: structure, distribution and predators. Geol. Rdsch. 61: 483-519

Grant, P. R., Abbott, I. (1980). Interspecific competition, island biogeography and null hypotheses. Evolution 34: 332-341

Gravier, M. C. (1910). Sur la lutte pour l'éxistance chéz les Madréporaires des récifs coralliens. C. r. hebd. Séanc. Acad. Sci., Paris 151: 955-956

Hidaka, M., Yamazato, K. (1984). Intraspecific interactions in a scleractinian coral, Galaxea fasicularis: induced formation of sweeper tentacles. Coral Reefs 3: 77-86

Jackson, J. B. C. (1977). Competition on marine hard substrata: the adaptive significance of solitary and colonial strategies. Am. Nat. 111: 743-767

Karlson, R. H., Jackson, J. B. C. (1981). Competitive networks and community structure: a simulation study. Ecology 62: $670-678$

Lang, J. C. (1973). Coral reef project - papers in memory of Dr. T. F. Goreau. II. Interspecific aggression by scleractinian corals 2 . Why the race is not only to the swift. Bull. mar. Sci. 23: 260-279

Logan, A. (1984). Interspecific aggression in hermatypic corals from Bermuda. Coral Reefs 3: 131-138

Neudecker, S. (1979). Effects of grazing and browsing fishes on the zonation of corals in Guam. Ecology 60: 666-672

Nishihira, M. (1982). Interactions of alcyonaria with hermatypic corals on an Okinawan reef flat. (Abstr.) Proc. 4th Int. Coral Reef Symp. Manila, 1981, p. 722

Pickard, G. L (1977). A review of the physical oceanography of the Great Barrier Reef and Western Coral Sea. Aust. Inst. Mar Sci. Monogr. Ser 2

Porter, J W. (1974). Community structure of coral reefs on opposite sides of the Isthmus of Panama. Science 186: 543-545

Porter, J. W. (1976). Autotrophy, heterotrophy, and resource partitioning in Caribbean reef corals. Am. Nat. 110: $731-742$

Potts, D. C. (1976). Growth interactions among morphological variants of the coral Acropora palifera. In: Mackie, G. O. (ed.) Coelenterate ecology and behaviour. Plenum Press, New York, p. 79-88

Richardson, C. A., Dustan, P., Lang, J. C. (1979). Maintainance of living space by sweeper tentacles of Montastrea cavernosa, a Caribbean reef coral. Mar. Biol. 55: 181-186

Rosen, B. R. (1981). The tropical high diversity enigma - the coral's eye view. In: Forey, P. L. (ed.) Chance, change and challenge. The evolving biosphere. British Mus. (Nat. Hist.) and Cambridge Univ. Press, p. 103-129

Sammarco, P. W. (1980). Diadema and its relationship to coral spat mortality: grazing, competition and biological disturbance. J. exp. mar. Biol. Ecol. 45: 245-272

Sammarco, P. W. Coll, J. C., LaBarre, S., Willis, B. (1983). Competitive strategies of soft corals (Coelenterata: Octocorallia): allelopathic effects on selected scleractinian corals. Coral Reefs 1: 173-178

Sheppard, C. R. C. (1979). Interspecific aggression between reef corals with reference to their distribution. Mar. Ecol. Prog. Ser. 1: 273-247

Sheppard, C. R. C. (1980). Coral cover, zonation und diversity 
on reef slopes of Chagos atolls, and population structures of the major species. Mar. Ecol. Prog. Ser. 2: 193-205

Sheppard, C. R. C. (1982a). 'Reach' of aggressively interacting corals, and relative importance of interactions at different depths. Proc. 4th Int. Coral Reef Symp. Manila, 1981, 2: 363-368

Sheppard, C. R. C. (1982b). Coral populations on reef slopes and their major controls. Mar. Ecol. Prog. Ser. 7: 83-115
Weinberg, S. (1981). A comparison of coral reef survey methods. Bijdr. Dierk. 51: 199-218

Wellington, G. M. (1980). Reversal of digestive interactions between Pacific reef corals: mediation by sweeper tentacles. Oecologia (Berl.) 47: 340-343

Williams, D. MCB. (1982). Patterns in the distribution of fish communities across the Great Barrier Reef. Coral Reefs 1: $35-43$

This paper was submitted to the editor; it was accepted for printing on July 2, 1985 